\title{
Application of Ceramic Powder as Supplementary Cementitious Material in Lime Plasters
}

\author{
Monika ČÁCHOVÁ ${ }^{1}$ *, Eva VEJMELKOVÁ ${ }^{1}$, Dana KOŇÁKOVÁ ${ }^{1}$, Jaromír ŽUMÁR ${ }^{1}$, \\ Martin KEPPERT ${ }^{1}$, Pavel REITERMAN ${ }^{2}$, Robert ČERNÝ ${ }^{1}$
}

\author{
${ }^{1}$ Department of Materials Engineering and Chemistry, Faculty of Civil Engineering, Czech Technical University in Prague, \\ Thákurova 7, 16629 Praha 6, Czech Republic \\ ${ }^{2}$ Experimental Centre, Faculty of Civil Engineering, Czech Technical University in Prague, Thákurova 7, 16629 Praha 6, \\ Czech Republic \\ cross $^{\text {ref }}$ http://dx.doi.org/10.5755/j01.ms.22.3.7433
}

Received 25 June 2014; accepted 23 December 2015

\begin{abstract}
In this paper, the properties of plasters based on lime - brick powder binder of varying composition (ceramics content from 0 to $80 \%$ ) are studied. The plasters are prepared with a constant water amount. The pore size distribution is thus influenced in a positive way; the total porosity increases with the ceramics content but the volume of capillary pores is reduced. It results in lower water vapor diffusion resistance factor while the apparent moisture diffusivity coefficient increases just moderately. The influence of ceramic on strength of plasters is not found very important. The thermal conductivity of plasters containing ceramics is lower than those with the pure lime what is again in agreement with the pore size distribution. It can be concluded that fine brick powder can be used as pozzolanic admixture in lime based plasters with a positive influence on its functional parameters.

Keywords: plaster, lime, ceramic powder, mechanical properties, hygric properties, thermal properties.
\end{abstract}

\section{INTRODUCTION}

Plaster was always a part of dwelling constructions, penthouses or stables for animals. History of plasters is very complicated. Plasters cannot be simply classified into architectural styles. Production technology of plasters and their application were part of heirloom. In the course of time, it was found out that the production technology depends on many aspects, such as the usage of basic raw materials, manipulation with fresh plaster mixtures and type of foundation. Elif Ugurlu and Hasan Boke researched historical brick plasters in environment with a higher relative humidity and temperature (at a spa) [1]. Vejmelková et al. searched for a possibility of lime replacement in plasters by some pozzolanic material and studied the effect of metakaolin on final plasters properties [2, 3].

One of the main efforts in materials engineering is to improve properties of conventional building materials with respect to environmental and economic parameters. We have combined two perspectives - classic pure lime plaster (traditional building material) with a content of a finely brick (waste material). The utilization of finely waste brick powder as pozzolanic component of lime mortars and plasters is a feasible way to obtain more durable and costeffective product. The fine ceramic powder is a waste originating in grinding process in the production of thermal insulation ceramic brick blocks.

The previous chemical analyses confirmed the pozzolanic activity [4] of finely brick powders which can assist in the creation of better bound connections. The main objective of this work is to find an appropriate ratio for the replacement of lime by a finely brick powder in plaster mixtures. Appropriate ratio of brick powder in new type of plaster was determined using selected parameters, namely the basic physical, hygric, thermal and mechanical properties

\section{MATERIAL}

The composition of studied plasters is shown in Table 1 . The lime-based plaster contains different percentage of a fine ceramic powder, which is produced as a waste by company Heluz s.r.o. (Czech Republic); the same waste was used in studies Holčapek [5] and Jogl [6]. The chemical composition of finely ceramic ash is given in Table 2 . This waste material is produced by grinding of calibrated ceramic thermal insulation blocks. The slaked lime CL $90 \mathrm{~S}$ (Table 3 ) is produced by the company Certovy schody a.s. The reference material is pure lime plaster labelled as LBR. Modified plasters with an increasing content of ceramic were labelled LB1 to LB6. The ratio of water and all dry substance (lime, brick powder and sand) was kept constant (0.2); consistency of plaster was tested according to [7].

\section{EXPERIMENTAL METHODS}

\subsection{Basic physical properties}

The basic physical properties were determined by help of specimens with the shape of cubes $50 \times 50 \times 50 \mathrm{~mm}$. Bulk densities $\rho\left[\mathrm{kg} / \mathrm{m}^{3}\right][8]$, matrix densities $\rho_{\text {mat }}\left[\mathrm{kg} / \mathrm{m}^{3}\right]$ and open porosities $\psi_{0}[\%]$ were determined by measurement of mass and dimensions of specimens in laboratory conditions. Drying of samples was performed in a drier at $80{ }^{\circ} \mathrm{C}$.

\footnotetext{
* Corresponding author. Tel.: +420-224-357130.

E-mail address: monika.cachova@fsv.cvut.cz. (M. Čáchová)
} 
Table 1. Composition of studied plasters

\begin{tabular}{|c|c|c|c|c|c|c|c|c|}
\hline \multirow{2}{*}{ Material } & \multirow{2}{*}{$\begin{array}{l}\text { Lime, } \\
\mathrm{kg}\end{array}$} & \multirow{2}{*}{$\begin{array}{l}\text { Brick powder, } \\
\text { kg }\end{array}$} & \multirow{2}{*}{$\begin{array}{c}\text { Brick } \\
\text { powder, } \\
\%\end{array}$} & \multicolumn{3}{|c|}{ Sand, kg } & \multirow{2}{*}{$\mathrm{w} / \mathrm{b}$} & \multirow{2}{*}{ Flow, mm } \\
\hline & & & & $0.3-0.8$ & $0.6-1.2$ & $1.0-40$ & & \\
\hline LBR & 3.75 & 0.00 & 0 & 3.75 & 3.75 & 3.75 & \multirow{7}{*}{0.2} & $130 / 130$ \\
\hline LB1 & 3.45 & 0.30 & 8 & 3.75 & 3.75 & 3.75 & & $155 / 155$ \\
\hline LB2 & 3.00 & 0.75 & 20 & 3.75 & 3.75 & 3.75 & & $165 / 165$ \\
\hline LB3 & 2.40 & 1.35 & 36 & 3.75 & 3.75 & 3.75 & & $155 / 160$ \\
\hline LB4 & 1.80 & 1.95 & 52 & 3.75 & 3.75 & 3.75 & & $160 / 160$ \\
\hline LB5 & 1.35 & 2.40 & 64 & 3.75 & 3.75 & 3.75 & & $160 / 160$ \\
\hline LB6 & 0.75 & 3.00 & 80 & 3.75 & 3.75 & 3.75 & & $180 / 180$ \\
\hline
\end{tabular}

Table 2. Chemical composition of finely brick powder

\begin{tabular}{|c|c|}
\hline Component & Amount, $\%$ \\
\hline $\mathrm{SiO}_{2}$ & 51.3 \\
\hline $\mathrm{Al}_{2} \mathrm{O}_{3}$ & 20.0 \\
\hline $\mathrm{Fe}_{2} \mathrm{O}_{3}$ & 6.0 \\
\hline $\mathrm{CaO}$ & 11.5 \\
\hline $\mathrm{MgO}$ & 4.5 \\
\hline $\mathrm{K}_{2} \mathrm{O}$ & 3.2 \\
\hline $\mathrm{Na}_{2} \mathrm{O}$ & 1.3 \\
\hline $\mathrm{TiO}_{2}$ & 0.8 \\
\hline $\mathrm{SO}_{3}$ & 1.0 \\
\hline
\end{tabular}

Table 3. Chemical composition of slaked lime

\begin{tabular}{|c|c|}
\hline Component & Amount, \% \\
\hline $\mathrm{CaO}+\mathrm{MgO}$ & $\geq 90$ \\
\hline $\mathrm{MgO}$ & $\leq 5$ \\
\hline $\mathrm{CO}_{2}$ & $\leq 4$ \\
\hline $\mathrm{SO}_{3}$ & $\leq 2$ \\
\hline Free lime & $\geq 80$ \\
\hline Water & $\leq 2$ \\
\hline Air & $\leq 12$ \\
\hline
\end{tabular}

After that cubes' masses $m_{d}[\mathrm{~kg}]$ were again measured and those samples were vacuum saturated by water [9], it means that samples were placed to the evacuated desiccator with water for at least 48 hours and weighed again in the saturated state $m_{w}$ and under the water level (with the help of Archimedes scales) $m_{a}[\mathrm{~kg}]$. Density of water is marked $\rho_{l}\left[\mathrm{~kg} / \mathrm{m}^{3}\right]$ and volume of specimen is marked $V\left[\mathrm{~m}^{3}\right]$. These measured values then were used for calculations:

$$
\begin{aligned}
& V=\frac{m_{w}-m_{a}}{\rho_{l}} ; \\
& \psi_{0}=\frac{m_{w}-m_{d}}{V \rho_{l}} ; \\
& \rho_{\text {mat }}=\frac{m_{d}}{V\left(1-\Psi_{0}\right)} ; \\
& \rho=\frac{m_{d}}{V} .
\end{aligned}
$$

The matrix density can be determined also by helium pycnometry. This experiment was carried out by device "Pycnomatic ATC" produced by company Thermo. This device has analogous principle as classic pycnometry.

\subsection{Pore system}

The pore system characteristics were measured by mercury intrusion porosimetry. This experiment was carried out by the devices "Pascal 140 and 440". The results are cumulative and incremental pore size distribution curves.

\subsection{Mechanical properties}

The standard three-point bending strength was determined by the device MTS 100 (by company MTS) while the distance between supports was $100 \mathrm{~mm}$. The compressive strength was determined by the device EU 40 . These measurements were performed on prisms with dimensions $40 \times 40 \times 160 \mathrm{~mm}$. The experiments were conducted according to the standard ČSN EN 1015-11 [10].

\subsection{Hygric properties}

Atmosphere contains water vapour, which can pervade porous material. Water vapour transport is described by water vapour diffusion coefficient $D\left[\mathrm{~m}^{2} / \mathrm{s}\right]$, which was obtained employing cup methods (the dry and wet cup method [11]). The idea is to make two environments with different relative humidity and separate them by the sample. Water vapour transport is then going on from the place with higher partial pressure to the place with lower partial pressure. The cup methods were using circular samples with diameter of $120 \mathrm{~mm}$. The cups were placed in a controlled climatic chamber with $50 \%$ relative humidity. In the dry cup method silica gel was used, while in the wet cup method water was placed in the cup. The cups were periodically weighed.

The moisture diffusivity $\kappa\left[\mathrm{m}^{2} / \mathrm{s}\right]$ was determined by a simple absorption experiment [12]. The studied materials were immersed 1-2 $\mathrm{mm}$ to water. The mass gain was recorded by a digital scale and special computer program. The water absorption coefficient $A\left[\mathrm{~kg} / \mathrm{m}^{2} \mathrm{~s}^{1 / 2}\right]$ was determined from measured data.

The measurement of sorption isotherm was performed by the device DVS Advantage 2. The studied material was put into a special steel tube and different values of relative humanity $(0,20,40,60,80$ and $98 \%)$ were set [13].

\subsection{Thermal properties}

The thermal conductivity $\lambda[\mathrm{W} / \mathrm{m} \mathrm{K}]$ and specific heat capacity $c[\mathrm{~J} / \mathrm{kg} \mathrm{K}]$ were determined by the device ISOMET 2104 - Applied Precision. ISOMET 2104 [14] is a portable and nonstationary device. Its measurement is based on the analysis of the temperature response of the analyzed material to heat flow impulses. The heat flow is induced by electrical heating using a resistor heater having a direct thermal contact with the surface of the sample. Thermal properties are strongly influenced by the material's moisture content. The measurement was done on the samples with dimensions of $70 \times 70 \times 70 \mathrm{~mm}$ in dried state as well as in water saturated state. 


\section{EXPERIMENTAL RESULTS}

\subsection{Basic physical properties}

The values of the basic physical properties measured by the water vacuum saturation method are given in Table 4. For comparison they were measured also by the helium pycnometer (Table 5). The vacuum saturation method provided somewhat lower values of porosity since it corresponds to open porosity while the results of helium pycnometry describe the total porosity. The values of bulk and matrix density vary slightly. The dependency of bulk densities on amount of ceramic admixture has convex character. The values of open porosity show no great difference, by water vacuum saturation $4 \%$ and by helium pycnometer $3 \%$.

Table 4. Basic physical properties obtained by water vacuum saturation method

\begin{tabular}{|c|c|c|c|}
\hline Material & $\rho, \mathrm{kg} / \mathrm{m}^{3}$ & $\rho_{\text {mat }} \mathrm{kg} / \mathrm{m}^{3}$ & $\psi_{0}, \%$ \\
\hline LBR & 1811 & 2554 & 31.1 \\
\hline LB1 & 1794 & 2588 & 32.9 \\
\hline LB2 & 1761 & 2598 & 34.9 \\
\hline LB3 & 1759 & 2613 & 35.0 \\
\hline LB4 & 1762 & 2614 & 35.2 \\
\hline LB5 & 1770 & 2565 & 34.1 \\
\hline LB6 & 1785 & 2593 & 33.2 \\
\hline
\end{tabular}

Table 5. Basic physical properties obtained by helium pycnometry

\begin{tabular}{|c|c|c|c|}
\hline Material & $\rho, \mathrm{kg} / \mathrm{m}^{3}$ & $\rho_{\text {mat }}, \mathrm{kg} / \mathrm{m}^{3}$ & $\psi, \%$ \\
\hline LBR & 1760 & 2590 & 32.1 \\
\hline LB1 & 1750 & 2609 & 32.9 \\
\hline LB2 & 1703 & 2616 & 34.9 \\
\hline LB3 & 1709 & 2631 & 35.0 \\
\hline LB4 & 1706 & 2632 & 35.2 \\
\hline LB5 & 1734 & 2630 & 34.1 \\
\hline LB6 & 1765 & 2644 & 33.2 \\
\hline
\end{tabular}

\subsection{Pore system}

Fig. 1 and Fig. 2 show the pore size distribution curves of the studied plasters. In the figures a growth of the open porosity and, thus, different pore distributions (quantity and size) can be seen. Reference sample LBR has maximum of pores with the diameter about $0.5 \mu \mathrm{m}$ while plasters with ceramic powder show the maximum of pores with diameter about $1.0 \mu \mathrm{m}$ (Fig. 1). This fact has an influence on materials properties.

\subsection{Mechanical properties}

The values of mechanical properties (bending strength, compressive strength) of studied plasters are given in Table 6. The results correspond to the measured values of open porosity. By adding the ceramic admixture the values of the compressive and bending strength decrease. The plasters with the highest dosage of pozzolanic admixture (LB5, LB6) show increase of compressive strength but they reach lower values than pure lime plaster (LBR). Similar mechanical results with brick powder in mortars were presented in other studies $[15,16]$.

\subsection{Hygric properties}

Table 7 and Table 8 show values of water vapour diffusion parameters of all studied plasters; results from dry cup and wet cup arrangements are presented. The values of the water vapour diffusion coefficient $D$ increase with a growing pozzolanic admixture ratio. The values of the water vapour diffusion resistance factor $\mu$ decrease with an increasing pozzolanic admixture ratio.

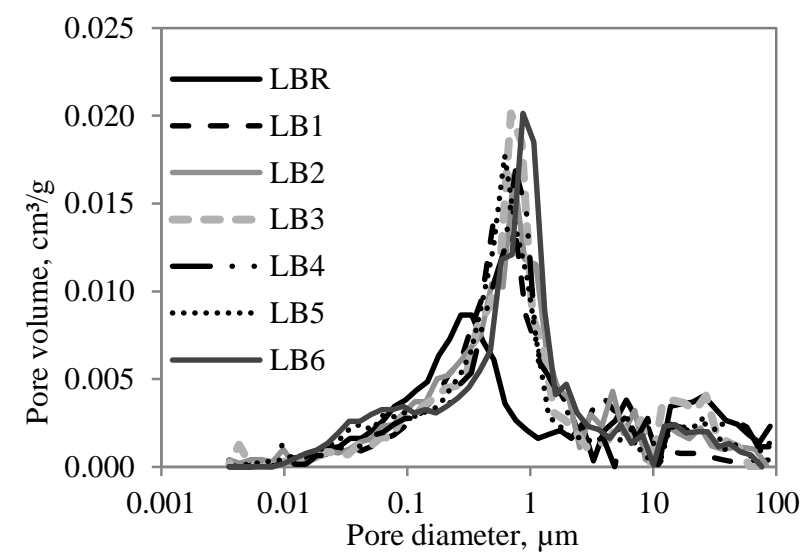

Fig. 1. Incremental pore size distribution curves

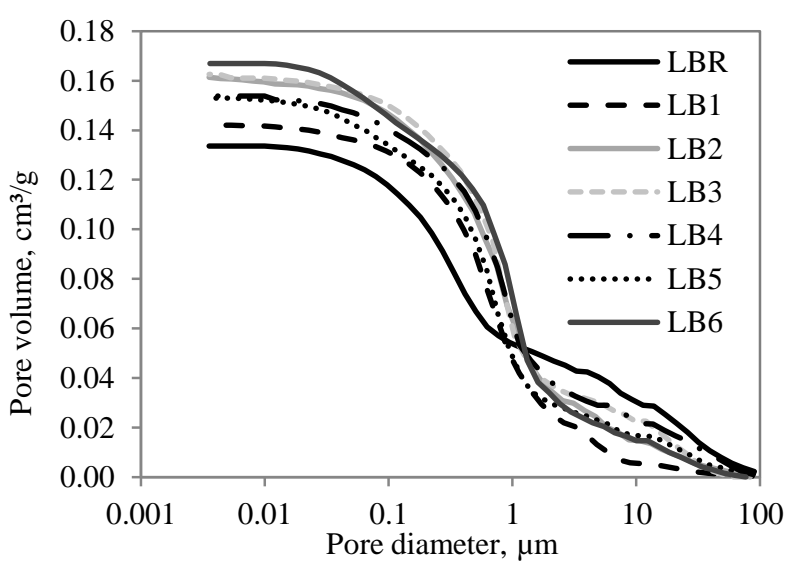

Fig. 2. Cumulative pore size distribution curves

Table 6. Mechanical properties

\begin{tabular}{|c|c|c|}
\hline Material & $\begin{array}{c}\text { Bending strength, } \\
\mathrm{MPa}\end{array}$ & $\begin{array}{c}\text { Compressive strength, } \\
\mathrm{MPa}\end{array}$ \\
\hline LBR & 0.62 & 1.71 \\
\hline LB1 & 0.52 & 1.53 \\
\hline LB2 & 0.49 & 1.43 \\
\hline LB3 & 0.43 & 1.39 \\
\hline LB4 & 0.40 & 1.37 \\
\hline LB5 & 0.37 & 1.47 \\
\hline LB6 & 0.38 & 1.53 \\
\hline
\end{tabular}

Table 7. Water vapour transport properties - dry cup

\begin{tabular}{|c|c|c|}
\hline Material & $D, \mathrm{~m}^{2} / \mathrm{s}$ & $\mu,-$ \\
\hline LBR & $6.20 \mathrm{E}-07$ & 37.12 \\
\hline LB1 & $6.53 \mathrm{E}-07$ & 35.41 \\
\hline LB2 & $6.75 \mathrm{E}-07$ & 34.09 \\
\hline LB3 & $6.95 \mathrm{E}-07$ & 33.13 \\
\hline LB4 & $7.16 \mathrm{E}-07$ & 32.16 \\
\hline LB5 & $9.15 \mathrm{E}-07$ & 25.15 \\
\hline LB6 & $9.73 \mathrm{E}-07$ & 24.25 \\
\hline
\end{tabular}

The value of water vapour diffusion coefficient $D\left[\mathrm{~m}^{2} / \mathrm{s}\right]$ of plaster LB6 grows by $36 \%$ (dry cup) in comparison with the reference lime plaster LBR. The value of the water vapour diffusion resistance factor $\mu$ [-] of plaster LB6 decreases by $35 \%$ (dry cup) and by $17 \%$ (wet cup) in comparison with the lime plaster LBR. The 
difference between results of the dry cup and wet cup methods was already observed in other cases; it is probably due to the distortion of wet cup results by capillary condensed water transport [17].

Table 8. Water vapour transport properties - wet cup

\begin{tabular}{|c|c|c|}
\hline Material & $D, \mathrm{~m}^{2} / \mathrm{s}$ & $\mu,-$ \\
\hline LBR & $2.24 \mathrm{E}-06$ & 10.95 \\
\hline LB1 & $2.46 \mathrm{E}-06$ & 9.60 \\
\hline LB2 & $2.64 \mathrm{E}-06$ & 8.89 \\
\hline LB3 & $2.79 \mathrm{E}-07$ & 8.24 \\
\hline LB4 & $2.55 \mathrm{E}-06$ & 9.02 \\
\hline LB5 & $2.51 \mathrm{E}-06$ & 9.19 \\
\hline LB6 & $2.54 \mathrm{E}-06$ & 9.09 \\
\hline
\end{tabular}

Liquid water transport properties of studied materials are given in Table 8 . The values of the water absorption coefficient $A\left[\mathrm{~kg} / \mathrm{m}^{2} \mathrm{~s}^{1 / 2}\right]$ increase with an increasing pozzolanic admixture ratio. The value of the water absorption coefficient $A$ of plaster LB6 increases 2 times in comparison with lime plaster LBR. For better illustration of water absorption process of studied plasters, graphs of cumulative moisture increment are given in Fig. 3.

Table 9. Liquid water transport parameters

\begin{tabular}{|c|c|c|}
\hline Material & $A, \mathrm{~kg} / \mathrm{m}^{2} \mathrm{~s}^{1 / 2}$ & $\kappa, \mathrm{m}^{2} / \mathrm{s}$ \\
\hline LBR & 0.0998 & $1.359 \mathrm{E}-07$ \\
\hline LB1 & 0.1533 & $2.645 \mathrm{E}-07$ \\
\hline LB2 & 0.1728 & $3.054 \mathrm{E}-07$ \\
\hline LB3 & 0.1849 & $3.677 \mathrm{E}-07$ \\
\hline LB4 & 0.1871 & $3.421 \mathrm{E}-07$ \\
\hline LB5 & 0.1748 & $2.859 \mathrm{E}-07$ \\
\hline LB6 & 0.2049 & $4.352 \mathrm{E}-07$ \\
\hline
\end{tabular}

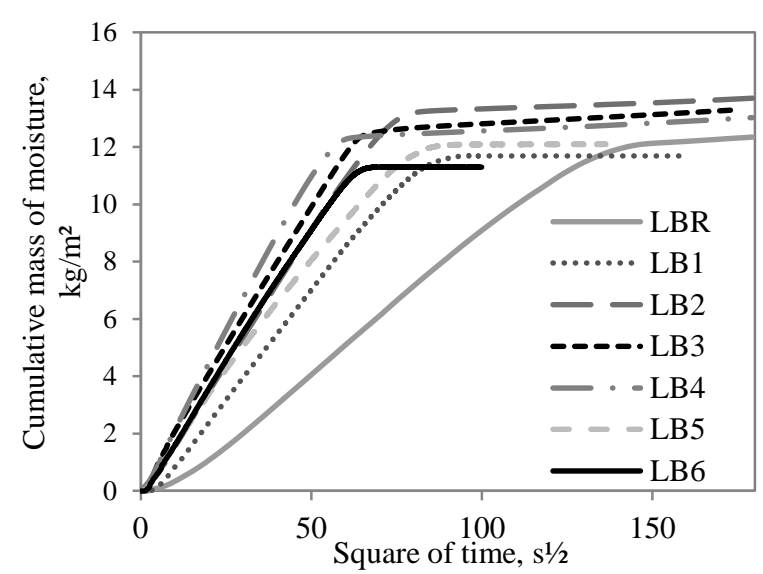

Fig. 3. Cumulative moisture increments

Fig. 4 and Fig. 5 show the sorption and desorption isotherm of studied materials. One can see that with an increasing pozzolanic admixture ratio the material's ability of relative humidity absorption grows. These results correspond to the characteristics of the pore system.

\subsection{Thermal properties}

Thermal properties of studied plasters are given in Table 10 (in dry state) and Table 11 (in water saturated state). The highest values of thermal conductivity $\lambda$ show the reference plaster LBR. The values of thermal conductivity decrease with an increasing ceramic admixture ratio. The values of specific heat capacity $c_{u}$ vary slightly. The thermal conductivity of plaster LB6 decreases by $50 \%$ in the dry state and by $10 \%$ in the saturated state in comparison with lime plaster LBR.

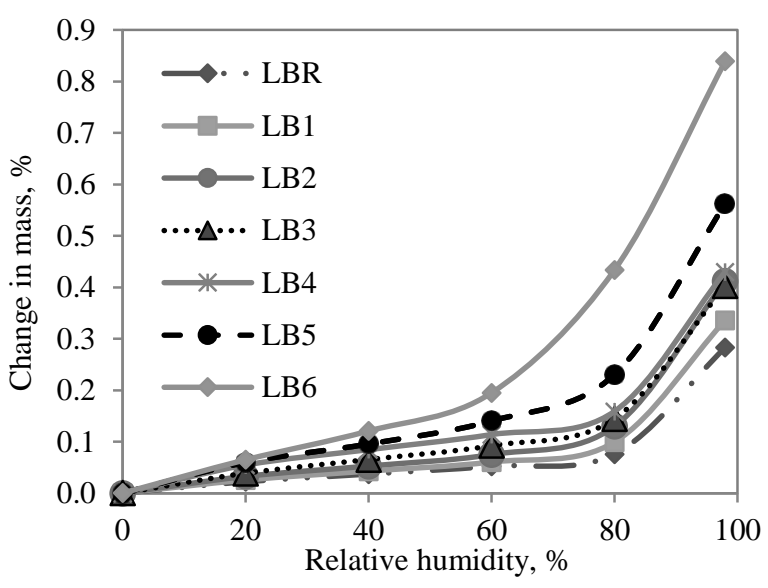

Fig. 4. Sorption isotherms of studied plasters

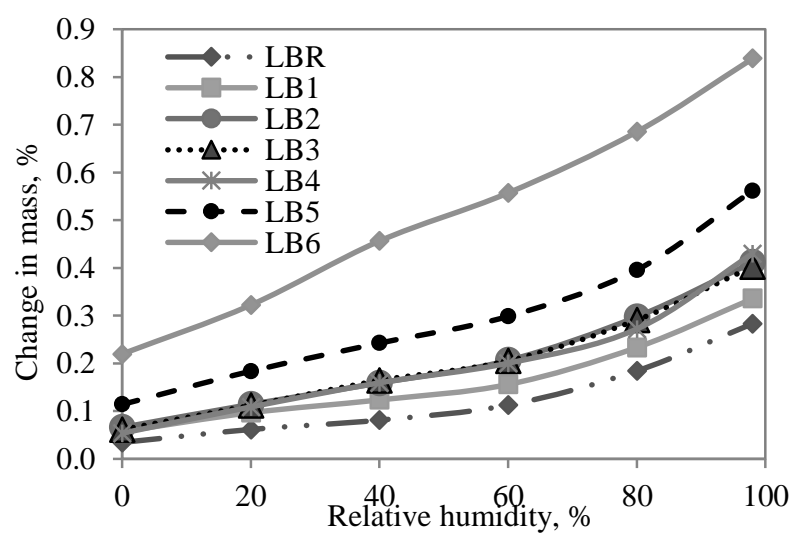

Fig. 5. Desorption isotherms of studied plasters

Table 10. Thermal properties of studied plasters in the dry state

\begin{tabular}{|c|c|c|c|}
\hline Material & $w, \% \mathrm{~m}^{3} / \mathrm{m}^{3}$ & $\lambda, \mathrm{W} / \mathrm{mK}$ & $c_{\mathrm{u},} \mathrm{J} / \mathrm{kgK}$ \\
\hline LBR & 0.00 & 1.35 & 807 \\
\hline LB1 & 0.00 & 0.92 & 817 \\
\hline LB2 & 0.00 & 0.81 & 846 \\
\hline LB3 & 0.00 & 0.77 & 851 \\
\hline LB4 & 0.00 & 0.75 & 857 \\
\hline LB5 & 0.00 & 0.79 & 831 \\
\hline LB6 & 0.00 & 0.71 & 841 \\
\hline
\end{tabular}

Table 11. Thermal properties of the studied materials in the saturated state

\begin{tabular}{|c|c|c|c|}
\hline Material & $w, \% \mathrm{~m}^{3} / \mathrm{m}^{3}$ & $\lambda, \mathrm{W} / \mathrm{mK}$ & $c_{\mathrm{u},} \mathrm{J} / \mathrm{kgK}$ \\
\hline LBR & 24.432 & 2.80 & 1208 \\
\hline LB1 & 26.837 & 2.57 & 1254 \\
\hline LB2 & 29.159 & 2.57 & 1319 \\
\hline LB3 & 27.833 & 2.52 & 1306 \\
\hline LB4 & 29.777 & 2.49 & 1338 \\
\hline LB5 & 28.320 & 2.56 & 1293 \\
\hline LB6 & 28.846 & 2.52 & 1305 \\
\hline
\end{tabular}

\section{CONCLUSIONS}

In this article new types of plasters with an addition of brick powder were investigated. The fine brick powder is a waste originating in grinding process in production of thermal insulation ceramic brick blocks. The aim of the 
study was to find out appropriate application of this secondary raw material.

The values of basic physical properties (bulk density, matrix density and open porosity) varied slightly. Pore systems showed different structure, reference sample LBR had the highest amount of pores with diameter about $0.5 \mu \mathrm{m}$ while plasters with ceramic powder showed maximum of pores with diameter about $1.0 \mu \mathrm{m}$. The effect of ceramic admixture on the mechanical properties was manifested by a convex function, at first the values of compressive strength went down, while in higher amount of addition they started to grow. The values of the water vapor diffusion coefficient $D$, water absorption coefficient $A$ and sorption isotherm increased with an increasing pozzolanic admixture ratio. The values of thermal conductivity $\lambda$ decreased with an increasing ceramic admixture ratio, but the values of specific heat capacity $c_{u}$ varied slightly. The plaster LB6 was the best thermal insulator.

Regarding the presented results, the best solution seemed to be the material with $8 \%$ of brick powder. However from the ecological and economical point of view, plaster containing $20 \%$ of finely ceramic powder represented a more effective utilization of waste material. This plaster labelled as LB2 achieved appropriate properties for its good applicability and also contained a sufficient amount of waste admixture.

\section{Acknowledgement}

This research has been supported by grant SGS13/165/OHK1/3T/11 and by the Ministry of Industry and Trade of the Czech Republic, under project No FRTI4/014.

\section{REFERENCES}

1. Ugurlu, E., Boke, H. The Use of Brick-Lime Plasters and Their Relevance to Climatic Conditions of Historic Bath Buildings Construction and Bulding Materials 23 (6) 2009: pp. $2442-2450$.

2. Vejmelková, E., Pernicová, R., Sovjak, R., Černý, R. Properties of Innovative Renders on a Lime Basis for the Renovation of Historical Buildings Structural Studies, Repairs And Maintenance Of Heritage Architecture XI 110 2009: pp. $221-229$.

3. Vejmelková, E., $\quad$ Keppert, M., Kerner, Z., Rovnaníková, P., Černý, R. Mechanical, FractureMechanical, Hydric, Thermal, and Durability Properties of Lime-Metakaolin Plasters for Renovation of
Historical Buildings Construction and Building Materials 31 2012: pp. $22-28$.

4. Pereira-de-Oliveira, L.A., Castro-Gomes, J.P., Santos Pedro, M.S. The Potential Pozzolanic Activity of Glass and Red-Clay Ceramic Waste as Cement Mortars Components Construction and Building Materials 31 2012: pp. $197-203$.

5. Holčapek, O., Reiterman, P., Konvalinka, P. High Temperature Composite of Aluminous Cement with Addition of Metakaolin and Ground Bricks Dust 51st Annual of the International Scientific Conference on Experimental Stress Analysis 486 2013: pp. 406-411.

6. Jogl, M., Reiterman, P., Holčapek, O., Vogel, F., Kolář, K., Kot’átková, J. Analysis of Mechanical Properties of a Fibre Composite Containing Secondary Raw Materials Advanced Materials Research 2015: pp. 129-134.

7. ČSN EN 1015-3: Methods of Test for Mortar for Masonry Part 3: Determination of Consistence of Fresh Mortar (by flow table). Prague 2000.

8. ČSN EN 1015-10: Methods of Test for Mortar for Masonry Part 10: Determination of Dry Bulk Density of Hardened Mortar. Prague 2000.

9. Roels, S., Carmeliet, J., Hens, H., Adan, O., Brocken, H., Černý, R., Pavlík, Z., Hall, C., Kumaran, K., Pel, L., Plagge, R. Interlaboratory Comparison of Hygric Properties of Porous Building Materials Journal of Thermal Envelope and Building Science 27 2004:pp. 307-325.

10. ČSN EN 1015 - 11: Determining the Strength of Hardened Mortar Bending and Compressive, Prague 2000.

11. ČSN 72 7031: Determination of Water Vapour Diffusion Coefficient of Building Materials by Method Without Temperature Gradient. Prague 2001.

12. Kumaran, M.K. Moisture Diffusivity of Building Materials from Water Absorption Measurements Journal of Thermal Envelope and Building Science 22 1999: pp. 349-355.

13. Pavlík, Z., Žumár, J., Medvěd, I., Černý, R. Water Vapor Adsorption in Porous Building Material: Experimental Measurement and Theoretical Analysis Transport in Porous Media 91 (3) 2012: pp. 939-954. http://dx.doi.org/10.1007/s11242-011-9884-9

14. Applied Precision - ISOMET. User manual, Bratislava, 1999.

15. Naceri, A., Hamina, M.C. Use of Waste Brick as a Partial Replacement of Cement in Mostar Waste Management 29 (8) 2009: pp. $1278-84$.

16. Navrátilová, E., Rovnaníková, P. Reactivity of Brick Powder in Lime Mortars Advanced Materials Research 897 2014: pp. $135-138$.

17. Černý, R., Rovnaníková, P. Transport Processes in Concrete Spon Press, 0-415-24264-9 London 2002. 